\title{
Power Distribution Transformers using Natural Ester Fluids as Dielectric and Coolant
}

\section{Transformadores de Distribución que operan con Aceite de Origen Vegetal como Dielectrico y Refrigerante}

\author{
DOI: http://dx.doi.org/10.17981/ingecuc.12.2.2016.08
}

Artículo de Investigación Científica - Fecha de Recepción: 27 de Junio de 2016, Fecha de Aceptación: 21 de Agosto de 2016,

Jorge Iván Silva-Ortega

Energy Optimization Research Group (GIOPEN). Universidad de la Costa. Barranquilla (Colombia) jsilva6@cuc.edu.co

$$
\text { Jhon Zapata-Rivera }
$$

Energy Optimization Research Group (GIOPEN). Universidad de la Costa. Barranquilla (Colombia) jzapata8@cuc.edu.co

Jhon Edwin Candelo-Becerra

Research Group on Applied Tecnologies (GITA), Universidad Nacional de Colombia. Sede Medellín. Medellín (Colombia) jecandelob@unal.edu.co

Nivaldo Rosales-Hernández

Electricaribe S.A. E.S.P. Barranquilla (Colombia) nrosalesh@electricaribe.com

\section{Samir Francisco Umaña-Ibañez}

Productivity and Competitiveness Group (PRODUCOM), Universidad de la Costa. Barranquilla (Colombia) sumana1@cuc.edu.co

\section{Mario Andrés Mejia-Taboada}

Energy Optimization Research Group (GIOPEN), Universidad de la Costa. Barranquilla (Colombia) mmejia6@cuc.edu.co

Alan Rafael Palacio-Bonill

Energy Optimization Research Group (GIOPEN), Universidad de la Costa. Barranquilla (Colombia) apalacio8@cuc.edu.co

\section{Melissa Torregroza Rosas}

Master in Electric Engineering. Universidade Federal de Itajubá. Minas Gerais (Brasil) melissatorregrozarosas@gmail.com

Cómo citar este artículo:

J. Silva-Ortega, J. Zapata-Rivera, J. Candelo-Becerra, N. Rosales-Hernandez, S. Umaña-Ibañez, M. Mejia-Taboada, A. Palacio-Bonill and M. Torregroza, "Power distribution transformers using natural ester fluids as dielectric and coolant", INGE CUC, vol. 12, No. 2, pp.79-85, 2016. DOI: http://dx.doi.org/10.17981/ingecuc.12.2.2016.08

\begin{abstract}
Researches related with the use of Natural Ester Fluids as refrigerant of power transformers has been developed in other countries with successful results. In Colombia there is no a procedure to control the use of these esters in electrical apparatus, so the current implementations are regulated by NTC 1465 standards for mineral esters. This new proposal involves the composition and the most relevant properties (the ignition resistance, impact on the lifetime of the insulating papers and the impact on the environment), which makes the application of natural esters fluids advantageous not only to preserve the environment but also to get a better performance of power transformers.
\end{abstract}

Keywords- Natural Ester Fluid, distribution transformers, electrical apparatus, environment, chemical properties.
Resumen- Las investigaciones en desarrollo respecto al uso de aceites de origen vegetal como refrigerantes en transformadores de distribución han tenido resultados destacados en otros países. En Colombia no existe un procedimiento para monitorear la aplicación de estos aceites en equipos eléctricos, por lo tanto la actual implementación se regula por la norma técnica NTC 1465 para aceites de origen mineral. Esta propuesta de nueva tecnología contempla la composición y las propiedades más relevantes (resistencia a la ignición, impacto en el tiempo de vida del papel e impacto en el medio ambiente), lo cual provee de mayor número de ventajas al aceite vegetal y un mejor desempeño en eficiencia.

Palabras clave- Aceite de origen vegetal, transformadores de distribución, equipos eléctricos, medio ambiente, propiedades químicas. 


\section{INTRODUCTION}

Power transformers started to use natural ester fluids as is the case of a Panama Utility where a pad-Mounted transformer operates with ester fluids as coolant. Patents and regulations have been presented in order to guarantee their production, commercialization and final use. The American Section of the International Associations for Testing Materials (ASTM) has regulated their technical specification.

The Colombian Technical Normative (NTC) adopted requirements for these natural esters fluids based on ASTM. This survey cover two perspectives: the regulatory specifications for natural ester fluids used in electrical apparatus as transformers taking into account their electrical, physics and chemical characteristic. For another hand the survey refers to important issues on natural ester fluids. Also, this paper consolidates results of a survey developed by utilities in Caribbean Coast of Colombia.

\section{Regulatory Specification for Natural Ester Fluids used in Electrical Apparatus}

In Colombia, the technical standard NTC 1465 establishes requirements for mineral ester fluids used in equipment such as transformers, switches and electrical apparatus [1].

However, the NTC 1465 only establishes the requirements to be accomplished by electric systems and apparatus that use mineral ester fluids according with the technological availability in Colombia. Otherwise, NTC 1465 was focused in the reduction of Polychlorinated Biphenyls (PCB) that used to be inside of Mineral Ester Fluids. Therefore, the continuous process of investigation and the continuous research in reduce the dependence of fluids derived from mineral oil has brought the implementation of new materials in which is included the use of natural ester fluids as dielectrics [1], [2].

During the investigation process, a contrast of the available limits of operation established in NTC 1465 was done according with the established in

Table 1. Requirement Comparison that are Proposed in Astm D6871 (Specification for Natural Ester) and the NTC 1465 (Specification for Mineral Oil in Colombia derived from ASTM D3487) [1], [6], [30], [21], [22]

\begin{tabular}{|c|c|c|c|c|c|c|}
\hline No & Type & Characteristics & $\begin{array}{l}\text { Limit } \\
\text { values }\end{array}$ & $\begin{array}{c}\text { ASTM reference } \\
\text { normative used for } \\
\text { Natural Ester Oil }\end{array}$ & $\begin{array}{l}\text { Limit } \\
\text { values }\end{array}$ & $\begin{array}{l}\text { ASTM reference } \\
\text { normative used } \\
\text { for Mineral Oil }\end{array}$ \\
\hline 1 & \multirow{7}{*}{ Physicals } & Maximum Color & 1,0 & D1500 & 0,5 & D1500 \\
\hline 2 & & Visual examination & $\begin{array}{c}\text { Bright } \\
\text { and Clear }\end{array}$ & D1524 & Bright and Clear & D1524 \\
\hline 3 & & Maximum Fire Point $\left({ }^{\circ} \mathrm{C}\right)$ & 300 & D92 & 145 & D92 \\
\hline 4 & & Maximum Flash Point $\left({ }^{\circ} \mathrm{C}\right)$ & 275 & D92 & $63-80$ & D611 \\
\hline 5 & & Maximum Pour Point $\left({ }^{\circ} \mathrm{C}\right)$ & -10 & D97 & -30 & D97 \\
\hline 6 & & Relative density & 0,96 & D1298 & $0,865-0,91$ & D1298 \\
\hline 7 & & $\begin{array}{l}\text { Maximum Viscosity } \\
100^{\circ} \mathrm{C} / 40^{\circ} \mathrm{C}\end{array}$ & $15 / 50$ & D $445 / 88$ & "3/12 & D 445 \\
\hline 8 & \multirow{4}{*}{ Chemical } & Corrosive Sulfur & $\begin{array}{l}\text { No } \\
\text { corrosive }\end{array}$ & D1275 & Not corrosive & D1275 \\
\hline 9 & & neutralization Number & 0,06 & D974 & 0,025 & D974 \\
\hline 10 & & PCB content (PPM) & $\begin{array}{c}\text { No } \\
\text { detectable }\end{array}$ & D4059 & 50 & D4059 \\
\hline 11 & & Maximum water content & 200 & D1533 & 30 & D1533 \\
\hline 12 & \multirow{5}{*}{ Electrical } & Maximum Gassing tendency & 0 & D2300 & 15 & D2300 \\
\hline 13 & & $\begin{array}{l}\text { Dissipation factor @ } 60 \mathrm{~Hz} \\
25^{\circ} \mathrm{C} / 100^{\circ} \mathrm{C}\end{array}$ & $0,2 / 4,0$ & D924 & $0,05 / 0,3$ & D924 \\
\hline 14 & & $\begin{array}{l}\text { Dielectric Breakdown } \\
\text { before treatment }\end{array}$ & 30 & D877 & 30 & D877 \\
\hline 15 & & $\begin{array}{l}\text { Dielectric Breakdown } \\
\text { After treatment } \\
1 \mathrm{~mm}(0.04 \text { in.) gap / } \\
2 \mathrm{~mm}(0.08 \text { in.) gap }\end{array}$ & $20 / 35$ & D1816 & $28 / 56$ & D1816 \\
\hline 16 & & $\begin{array}{c}\text { Dielectric Breakdown voltage } \\
\text { under impulse conditions } \\
\left(25^{\circ} \mathrm{C}, \min , \mathrm{kV}\right)\end{array}$ & 130 & D3300 & 145 & D3300 \\
\hline
\end{tabular}


ASTM D6871. There were presented parameters for natural ester fluids operation, this comparison was done with sixteen properties in which were involved physical, chemical and electrical specifications that must be verified in both ester fluids types [3], [4], [5].

Table 1 resume the available specification for each type on fluids.

As is shown in table 1, the high performance of natural ester oils allows a higher fire point in contrast with mineral oils. The following considerations are relevant and advantageous for its implementation [2]:

a. Their Operation Compatibility with typical materials used in construction and assembly of electrical equipment.

b. Their natural origin from agricultural product which makes them less flammable.

c. They are free of Polychlorinated Biphenyls (PCB) due to its natural origin.

d. Their Greater fire point which make it resistant to adverse operative conditions during transient events.

ASTM 6871-03 suggests especial consideration considering the following properties: physical conditions (aniline point, interfacial tension pour point), chemical (water content, neutralization number, oxidation inhibitor content, oxidation stability) and electrical (dissipation factor). ASTM 6871-03 also establishes typical values to considerate during the filling process in which must be verified the proprieties of the natural ester fluids to validate its operation. Table 2 define the range value considered as typical and normative reference that allows testing processes [6].

Table 2. Common Properties for vegetable dielectric

\begin{tabular}{|c|c|c|}
\hline Proprieties & Typical Values & ASTM \\
\hline Expansion Coefficient $\left({ }^{\circ} \mathrm{C}^{-1}\right)$ & 0,0007 a 0,0008 & D1903 \\
\hline Dielectric Constant $@ 25^{\circ} \mathrm{C}$ & 3,1 a 3,3 & D924 \\
\hline Specific Heat & 0,45 a 0,6 & D2766 \\
\hline Thermal conductivity & 0,0035 a 0,0045 & D2717 \\
\hline
\end{tabular}

Previous works related with transformers that operate with natural ester fluids suggest the revision of some properties in order to be in rule with the standards specification presented in table 3 . These parameters are monitored during the survey allowing the identification of their performance in stable operation of the system as is the case of the temperature of the oil.

However water existence inside of the transformer as is established in ASTM D6871 allows that the natural ester fluids do not generate the proliferation of microorganisms inside of the transformer tank due to the presence of degraded oil considering a very dry environment for this species if it is kept lower than $300 \mathrm{ppm}$.

Table 3. Standard References For the Monitoring OF TRANSFormers that operates With Natural Ester Fluids

\begin{tabular}{|c|c|c|}
\hline Test & $\begin{array}{c}\text { During the } \\
\text { energizing } \\
\text { process }\end{array}$ & $\begin{array}{c}\text { During } \\
\text { Normal } \\
\text { operation }\end{array}$ \\
\hline Breakdown Voltage (kV) & IEC 60156 & IEC 60156 \\
\hline Moisture (ppm) & ASTM D1533 & IEC 60814 \\
\hline Acidity (mg of KOH/g of oil) & ASTM D974 & AS 1767.1 \\
\hline Interfacial Tension (mN/m) & ASTM D971 & ASTM D971 \\
\hline Dielectric Dissipation Factor & IEC 60247 & IEC 60247 \\
\hline
\end{tabular}

\section{III.Discussion: Fundamental Issues of Natural Ester Fluids}

In the following section are considered the most typical issues of Natural Ester fluids as their chemical composition, the most common values for their properties and their environmental impact.

\section{A. Composition}

Natural ester fluids usually come on its native form derived from soybean extracting oil processes. This natural ester consists of a mixture of fatty acids and saturated (without C-C double bonds) and unsaturated (with $\mathrm{C}-\mathrm{C}$ double bonds) esters. Fig. 1 shows the main molecular structure of several natural esters of native soybean oil. The percentage of unsaturated compounds in the mixture confers the dielectric and viscosity properties to the natural ester. It has been evidenced in [7], [8], where the more unsaturated compounds in the oil the more susceptible to degradation by oxidation and hydroxylation reactions. Additionally, it has been found that the increase in temperature and traces of iron $(\mathrm{Fe})$ and copper $(\mathrm{Cu})$ accelerates the oxidation processes. The most notable consequences resulting from the oxidation are 1) the decomposition products such as alcohols, aldehydes, ketones and acids, 2) the increase in the acidity, 3) the formation of polymerization products and 4) the increase in oil viscosity.

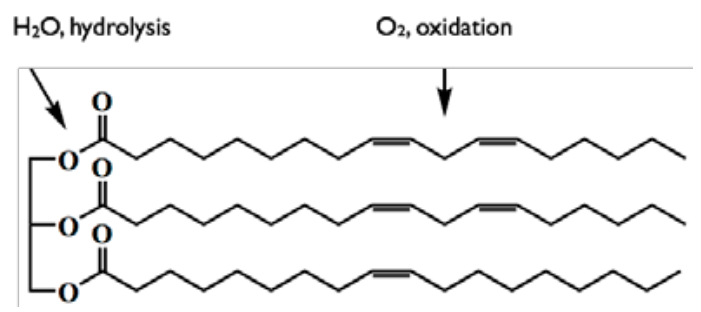

Fig. 1. Natural ester fluids molecular structure. Indicates the atoms which can carry out oxidation and hydrolysis reactions 
Also, moisture, oxygen and environmental pollution deteriorate the dielectric characteristics [9], [10]. Moisture and environmental pollutants reduce the dielectric strength of the fluid, while the oxygen atmosphere accelerates the processes of formation of sludge mainly formed by the decomposition of oils. To prevent or lessen all these degradation processes, it has been incorporated some additives to the natural ester fluids. Have been used mainly three types of additives:

Oxidation inhibitors: these compounds reduce the formation of resins, acids and polymers. These inhibitors are used gradually and must be renewed. Examples include the butylated hydroxyl toluene and the anisole in a ratio of $0.1-3.0 \%$.

Metal deactivators: these substances protect the metal surfaces to prevent corrosion. For example, to reduce reactions taking place in a $\mathrm{Cu}$ surface, benzotriazole derivatives are added in a proportion not exceeding $1.0 \%$.

Freezing point depressants: these substances reduce the freezing point which usually tends to be higher in mineral than in natural esters. These substances vary depending on the type of oil and producer. As shown in figure 2, the conventional process consists of a partial hydrogenation of fatty acids and esters in order to reduce the number of instaurations and therefore reduce the freezing point.

Furthermore, in Table 4 summarizes some characteristics in the composition of canola oil Rapsol-T, [11]. It serves as a source for the production of natural ester fluids used in the world market.

\section{B. Properties}

Since its development, vegetable dielectric oils have been characterized by various physical and chemical tests to determine a direct relationship between their properties and performance [12]. In Fig. 2. Hydrogenation reaction of fatty acids and esters. Metalbased catalysts accelerate the partial hydrogenation
Table 4. Properties of Rapsol T Canola Oil [11]

\begin{tabular}{|c|c|}
\hline Characteristic & Value \\
\hline \% palmitic acid & 4.8 \\
\hline \% estearic acid & 1.6 \\
\hline \% oleic acid & 60.0 \\
\hline$\%$ linoleic acid & 21.2 \\
\hline$\%$ linolenic acid & 9.8 \\
\hline Cloud point $\left({ }^{\circ} \mathrm{C}\right)$ & 0 \\
\hline Flash point $\left({ }^{\circ} \mathrm{C}\right)$ & $>220$ \\
\hline Acidity $($ mg $\mathrm{KOH} / \mathrm{g})$ & $<0.1$ \\
\hline$\%$ antioxidants & 0.1 \\
\hline$\%$ metal deactivators & 0.02 \\
\hline
\end{tabular}

Table 5 is shown the most relevant characteristics of various insulating fluids and the corresponding test method. Furthermore, although the literature has studied a wide variety of properties of natural ester fluids, this article describes the basis of three most improved properties respect to the mineral oil: resistance to ignition, impact on the aging of insulating papers and the impact on the environment. This latter property will be discussed in section $\mathrm{C}$.

Ignition resistance: among the main consequences of aging infrastructure of transformers, at least in Colombia, is the increase in the number of electrical faults. A smaller but still significant percentage of such failures found in transformer substations are considerable and often results in the burning of oil in which the transformer is immersed, and hampers extinction. These cremations can be prevented using vegetable dielectric oil, which are recognized as less flammable according to the "National Recognized Testing Laboratory" of USA [13].

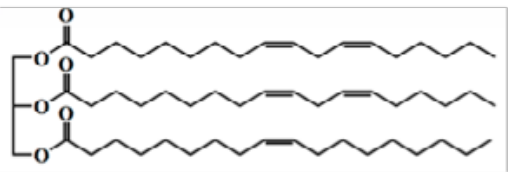

$\mathrm{H}_{2} /$ Catalyst

Partial hydrogenation<smiles>CCCCCCCCCCCCCCCCCCCCCC1OCC2COC(O)(OC2)O1</smiles>

$\mathrm{H}_{2} /$ Catalyst

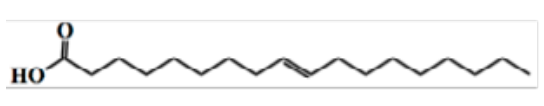

Elaidic acid

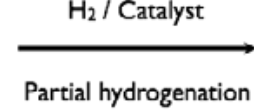

Partial hydrogenation

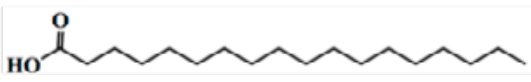

Estearic acid

Fig. 2. Hydrogenation reaction of fatty acids and esters. Metal-based catalysts accelerate the partial hydrogenation 
Table 5. Characteristics of some Insulating Fluids

\begin{tabular}{|c|c|c|c|c|c|c|}
\hline Characteristic & FR3 & R-TEMP & Conventional oil & Silicon oil & Synthetic esters & Test method \\
\hline Dielectric strength $(\mathrm{kV})$ & 56 & 52 & 45 & $35-70$ & 45 a 70 & ASTM D877 \\
\hline Viscosity $40^{\circ} \mathrm{C}$ & 33 & 113 & 9,2 & 39 & 14 a 29 & ASTM D455 \\
\hline Viscosity $100^{\circ} \mathrm{C}$ & 8 & 12 & 2,3 & 17 & 4 a 6 & ASTM D445 \\
\hline Fire point $\left({ }^{\circ} \mathrm{C}\right)$ & 324 & 276 & 147 & 300 & 250 a 270 & ASTM D92 \\
\hline Flash point $\left({ }^{\circ} \mathrm{C}\right)$ & 360 & 312 & 165 & 343 & 300 a 310 & ASTM D92 \\
\hline Pour point $\left({ }^{\circ} \mathrm{C}\right)$ & -21 & -22 & -50 & -55 & -40 a -50 & ASTM D97 \\
\hline Density $\left(\mathrm{kg} / \mathrm{dm}^{3}\right)$ & 0,92 & 0,87 & 0,87 & 0,96 & 0,9 a 1,00 & ASTM D1298 \\
\hline Specific hot $(\mathrm{J} / \mathrm{g} \cdot \mathrm{K})$ & 2,09 & 1,88 & 1,63 & 1,5 & 1,8 a 2,3 & ASTM D1269 \\
\hline Thermal conductivity $(\mathrm{W} / \mathrm{m} \cdot \mathrm{K})$ & 0,17 & 0,13 & $0,11-0,16$ & $0,16-0,17$ & 0,15 & CPS \\
\hline expansion coefficient $\left(10^{-4} / \mathrm{K}\right)$ & 7,4 & 7,3 & $7-9$ & 10 & 6,5 a 10 & CPS \\
\hline
\end{tabular}

The most critical property for determining the ignition resistance of the transformer fluids is the fire point. When immersed transformer is operating at full load, with an ambient temperature of $40^{\circ} \mathrm{C}$, the insulating fluid temperature is about $100^{\circ} \mathrm{C}$. Then, when electrical protective equipment does not work as expected, warming caused by an internal failure or chronic overload can increase the fluid temperature, which also causes the oil ignition. In mineral oils this phenomenon occurs with moderate rate while, conversely, in natural esters the fire point is much higher (typically above $300{ }^{\circ} \mathrm{C}$ ), in which the ignition is virtually impossible under conditions actual operation of the transformer [14].

Table 6 shows the self-ignition temperatures of most used natural ester fluids in transformers (the self-ignition temperatures are about $50{ }^{\circ} \mathrm{C}$ higher than the fire point) [15]. The ignition mechanism begins with an excessive heating of the fluid, thereby keeping vapor concentration increases significantly. Thus, initially the vapor is incinerated and then the combustion is maintained on the surface of the fluid. Other properties related to ignition resistance are self-extinction, ignition by electric current, the hot metal ignition and self-ignition. All these properties are improved by insulating oils of vegetable origins [16].

Table 6. Self-ignition temperatures by the ASTM 659

\begin{tabular}{|c|c|c|}
\hline \multirow{2}{*}{ Oil } & \multicolumn{2}{|c|}{ Self-ignition temperatures $\left({ }^{\mathbf{}} \mathbf{C}\right)$} \\
\cline { 2 - 3 } & Range & Average \\
\hline Mineral oil & $225-228$ & 226.5 \\
\hline R-Temp & $357-360$ & 358.5 \\
\hline Envirotemp 200 & $373-376$ & 374.5 \\
\hline Silicon oil DC 561 & $399-402$ & 400.5 \\
\hline Envirotemp FR3 & $401-404$ & 402.5 \\
\hline
\end{tabular}

Impact on the aging of insulating papers: it has been performed some test on a laboratory scale in which is evaluated the aging of the insulating papers used by conventional transformers. [17] have found that aging by thermal degradation of Kraft paper is considerably slower in natural ester than in mineral oil under the same thermal conditions. In tests on sealed containers at $170{ }^{\circ} \mathrm{C}$, paper aged in natural ester takes 5-8 times longer to reach the end-of-life point that the paper aged in mineral oil.

The test results also allow estimating that $110^{\circ} \mathrm{C}$, approximated operation temperature of the transformer, the end-of-life point of the paper immersed in natural ester is 2.5 times larger than the paper submerged in mineral oil. Since the paper is essentially cellulose, clearly there is a marked decrease in the thermal aging of the cellulose in natural ester dielectric fluids. It has been proposed two types of protection provided by the natural ester that improves the aging characteristics of cellulose: water sweeping and steric protection to the hydrolytic reactions of cellulose.

Water sweeping works in two ways. 1) At high temperatures, the natural ester can cause hydrolysis, removing water molecules from cellulose and thus reducing potential harm caused by water. 2) Natural ester can capture considerably more water than mineral oil. At room temperature, water saturation of the natural ester is $1050 \mathrm{mg} / \mathrm{kg}$, while for mineral oil is $60 \mathrm{mg} / \mathrm{kg}$, i.e., natural ester can absorb more water than the mineral oil, hence the former has a greater drying effect on the paper and thus decrease its aging [18].

On the other hand, the hydrolytic protection is carried out because natural ester can interfere with the process of cellulose hydrolysis due to thermal stress. Natural ester reacts with $\mathrm{OH}$ groups and terminal chains through a mechanism known as transesterification. Esterification's of the reactive $\mathrm{OH}$ sites of the cellulose with bulky steric groups stabilize the molecule and extend the life of the insulating paper [19]. 


\section{Environmental impact}

At present, the environmental impact caused by electrical processing equipment using mineral oil or some synthetic oils such as silicone or other hydrocarbons of low biodegradability is the subject of wide interest, especially when these apparatus are located in populated areas, in malls, parks or nearby watersheds. Most environmental surveillance agencies consider that spills of these oils are harmful to humans and the other living species.

Among the different factors that identify the environmental impact of dielectric oils are the biodegradability, thermal decomposition, oxidative degradation and arcing [20]. Biodegradability has been reported in the method CEC L-33 -A94 , where was found that the natural ester fluids have a $97 \%$ of biodegradability, while the mineral oils have only $30 \%$ when applied the same method. Thermal decomposition is similar in both species of dielectric oil. It basically produces carbon dioxide $\left(\mathrm{CO}_{2}\right)$, carbon monoxide (CO), hydrogen $\left(\mathrm{H}_{2}\right)$ and some hydrocarbons.

\section{Conclusions}

The use of natural ester fluids in electrical equipment brings some advantages not only in terms of equipment performance but also in terms of environmental impact. At the international level there are some ASTM standards governing the use of natural ester fluids on electric devices. However, in Colombia there is currently no rule governing the application of this technology. Current regulations are based on the application of mineral ester fluids with specific restrictions on the use of PCBs. This situation is an important point of analysis and towards which we can drive future researchers.

Regarding to the advantages of the application of natural esters, this paper summarizes the most relevant physicochemical characteristics to provide better performance. The ability to absorb more water than mineral oils (up to $1050 \mathrm{mg} / \mathrm{kg}$ ), its high fire point (greater than $300{ }^{\circ} \mathrm{C}$ ) and the flexibility to be combined with other compounds that allow inhibit oxidation, deactivate metals and reducing point freezing are features that provide better performance in electrical equipments.

On the other hand, it has been discussed the biodegradability of natural esters. The works reported in the literature indicate that natural esters degrade up to $97 \%$ within a remarkably short time, i.e., have a significantly shorter half-life. Also, the gas emission is reduced $1 / 4$ by Natural Ester Fluids respect to Mineral Ester Fluids.

\section{Perspectives}

This survey results from a pilot project, which evaluate the performance of conventional transformers immersed in natural ester fluids. From these results will be extracted knowledge to the creation of a new prototype specially adapted to the natural ester fluid refrigerant and climatic conditions of the main cities of Colombia.

\section{ACKNOWLEDGEMENTS}

Thanks to the Corporación Universidad de la Costa and the company Electricaribe S.A. E.S.P. for financial support of the project.

\section{REFERENCES}

[1] NTC1465, NTC 1465: Especificaciones para Aceites Minerales Nuevos. Aislantes para Transformadores, Interruptores y Equipos Eléctricos., Bogotá: Instituto Colombiano de Normas Técnicas ICONTEC, 2003.

[2] ASTM D 6871, D 6871 Standard Specification for Natural (Natural ester) Ester Fluids Used in Electrical Apparatus, United States: American Society for Testing and Materials, 2003.

[3] ASTM D 2717, D 2717 Test Method for Thermal Conductivity of Liquids3, United States: American Society for Testing and Materials, 1995.

[4] IEEE C57.147, C57.147-2008: Guide for Acceptance and Maintenance of Natural Ester Fluids in Transformers, New York: IEEE, 2008.

[5] D. Martin, N. Lelekakis y W. Guo, "Further Studies of a Vegetable-Oil-Filled Power Transformer", IEEE Electrical Insulation Magazine, vol. 27, n 5, pp. 6-14, 2011.

[6] D. F. Navas, H. Cadavid y D. F. Echeverry, "Aplicación del aceite dieléctrico de origen vegetal en transformadores eléctricos1” R,evista Ingeniería, vol. 16, $\mathrm{n}^{\circ} 1$, pp. 201-213, 2012

[7] U. Biermann and J. O. Metzge, "Application of Natural ester-Based Fluids as Transformer Oil.", Doctoral thesis, University of Oldenburg, Oldenburg, 2007.

[8] G. S. Cannon y L. A. Honary, "Soybean-based transformer oil and transmission line fluid. Waverly Light and Power", United States Patente USXXAM US 5958851 A 19990928, 1999.

[9] G. S. Cannon and J. A. Kotowsky, "Oxidation stability of native oils. Waverly Light and Power", United States Patente USXXAM US 6340658., 2002.

[10] H. Le Chien and Y. Bertrand, "Dielectric liquid compositions based on modified oleic rapeseed oil as insulating liquids and coolants, and electric devices containing them.", France Patente FRXXBL FR 2855527 A1 20041203., 2004.

[11] M. Hemmer, "Characterization of Rapeseed Oil-Based Fluids as Transformer Oil.”, Doctoral thesis Karlsruhe, University of Karlsruhe, 2004.

[12] C. P. McShane, J. Corkran, K. Rapp, and J. Luksich, "Natural ester dielectric fluid development", IEEE/PES Transmission and Distribution Conference and Exposition, 2006.

[13] Factory Mutual Global, Separation distance, property loss prevention data sheets (5-4 transformers, Section 2.3.1.1.1), 2004 
[14] National Fire Protection Association, Quincy, MA., NFPA 850: Recommended Practice for Fire Protection for Electric Generating Plants and High Voltage Direct Current Converter Stations., National Fire Protection Association, 2009.

[15] A. Argeros, D. Pincus, Z. Shinar, and A. Sultenfuss, "Heat of Combustion of Oils.", Undergraduate thesis, Pennsylvania: University of Pennsylvania, 1988.

[16] Chilworth Technology, Plainsboro N.J., "Process Safety Test Results and Interprestation for Envirotemp 200 Fluid, R-Temp Fluid, Tranelec Conventional Transformer Oil, Envirotemp FR3 Fluid, and DC 561 (Silicone Oil)", 2005.

[17] C. P. McShane, K. J. Rapp, J. L. Corkran, G. A. Gauger, and J. Luksich, "Aging of paper insulation in natural ester dielectric fluid", IEEE/PES Transmission and Distribution Conference and Exposition, 2001.

[18] M. Huang y X. LI, "Thermal degradation of cellulose and cellulose esters", Journal of applied polymer science, vol. 68, nº 2, pp. 293-304, 1998.

[19] R. K. Jain, K. Lal, and H. L. Bhatnagar, "A kinetic study of the thermal degradation of cellulose and its derivatives", Die Makromolekulare Chemie, vol. 183, no 12, pp. 3003-3017, 1982

[20] T. V. Oommen y C. C. Claiborne, "Biodegradable insulating fluid from high oleic natural esters", Cigré, pp. 15302, 1998.

[21] ASTM D 88, D 88 Test Method for Saybolt Viscosity. United States: American Society for Testing and Materials, 1956.

[22] ASTM D 97, D 97 Test Method for Pour Point of Petroleum Products. United States: American Socity for Testing and Materials, 2005.
[23] ASTM D 445, D 445 Test Method for Kinematic Viscosity of Transparent and Opaque Liquids (the Calculation of Dynamic Viscosity). United States: American Society for Testing and Materials, 1965.

[24] ASTM D 924, D 924 Test Method for Dissipation Factor (or Power Factor) and Relative Permittivity (Dielectric Constant) of Electrical Insulating Liquids. United States: American Society for Testing and Materials, 1990.

[25] ASTM 924 D 3300, 924 D 3300 Test Method for Dielectric Breakdown Voltage of Insulating Oils of Petroleum Origin Under Impulse Conditions. United States: Amercian Society for Testing and Materials, 2009.

[26] ASTM D 1816, D 1816 Test Method for Dielectric Breakdown Voltage of Insulating Oils of Petroleum Origin Using VDE Electrodes. United States: American Society for Testing and Materials, 1997.

[27] ASTM D 1903, D 1903 Test Method for Coefficient of Thermal Expansion of Electrical Insulating Liquids of Petroleum Origin, and Askarels. United States: American Society for Testing and Materials, 1996.

[28] ASTM D 2766, D 2766 Test Method for Specific Heat of Liquids and solids. United States: American Society for Testing and Materials, 1995.

[29] ASTM D 3487, D3487 Standard Specification for Mineral Insulating Oil Used in Electrical Apparatus. United States: American Society for Testing and Materials, 2009.

[30] ASTM D 92, D92 Test Method for Flash and Fire Points by Cleveland. United States: American Society for Testing and Materials, 1989. 